\title{
CAMINHADA “NA NATUREZA” E NATUREZA DA CAMINHADA: ETNOGRAFIA DE UMA AÇÃO GOVERNAMENTAL NA ÁREA RURAL DE IVAIPORÃ, PARANÁ ${ }^{1}$
}

\author{
Rodrigo Toniol*
}

\section{Introdução}

Temam e tremam em vossa presença todos os animais da Terra, todas as aves do Céu, e tudo o que tem vida e movimento na Terra. Em vossas mãos pus todos os peixes do mar. Sustentai-vos de tudo o que tem vida e movimento (Gênesis, 9:2-3)

No século XVIII o ato de trinchar a carne à mesa era um atributo social associado à nobreza e podia ser feito de diversas maneiras: "despedaçar esse cervo, quebrar as asas desse pato selvagem, desmembrar essa garça, mutilar esse pavão" (Doddrigde, Phillip, 1763, apud, Thomas, Keith, 2010)

Em meados do século XVII as montanhas eram odiadas como estéreis "deformidades", "verrugas", "furúnculos", "monstruosas excrescências", "refugo da terra", "pudenda da Natureza", cerca de um século depois, tinham-se transformado, em objetos da mais elevada admiração estética. (Thomas, Keith, 2010)

Após acelerar o passo e me separar do grupo com que havia iniciado a caminhada deparo-me, ainda no primeiro terço do percurso, com uma placa em madeira em que está talhado o quarto mandamento: "Honrar e respeitar a Natureza”. (Trecho de diário de campo 22 de agosto de 2010)

Como podem as montanhas passar de furúnculos a espaços sagrados em um curto período de tempo? Quais são os dispositivos que sustentam, promovem e transformam a relação Humano-Natureza? Iniciar com estas provocações é uma tentativa de desestabilizar o imperativo cartesiano que dicotomiza a relação sujeitoobjeto compondo um quadro no qual há um espaço, neste caso a Natureza, a-histórico, estático, sem corpo, a mercê de um cogito situado na história, dinâmico. O que está em jogo é um esforço por colocar o espaço da Natureza em relação ao tempo e aos sujeitos

\footnotetext{
${ }^{1}$ Uma primeira versão deste trabalho foi apresentada como monografia final do curso de Individualismo, Memória e Sociabilidade oferecido por Cornélia Eckert e Ana Luiza Carvalho da Rocha ministrado no Programa de PósGraduação em Antropologia Social - UFRGS. Agradeço aos comentários de Cornélia Eckert e Ariel Gravano.

* Mestrando em Antropologia Social pelo Programa de Pós-Graduação em Antropologia Social da Universidade Federal do Rio Grande do Sul - UFRGS. Email: rodrigo.toniol@gmail.com
} 
que nele habitam para, com isso, evitar a perspectiva que concebe a Natureza como um a priori, semelhante a um cenário, no qual a humanidade imprimi suas relações, temporalidades e experiências.

A temática mais ampla que assumo como ponto de partida para este trabalho trata dos múltiplos processos de ambientalização social ${ }^{2}$. Este fenômeno, conforme o concebo, é parte de uma série de transformações que têm contribuído para rotinizar e promover uma espécie de idioma ambiental não restrito ao âmbito ecológico, mas capaz de operar como paradigma moral, ético e estético. Vista sob certa amplitude esta temática está relacionada com modificações na articulação entre tempo, espaço e sujeito em determinada relação Humano-Natureza. Num esforço de problematização de alguns aspectos em jogo nestes contextos, elejo como foco de interesse empírico a promoção de caminhadas ecológicas como ação governamental, mais especificamente a I Caminhada Internacional na Natureza de Ivaiporã, Paraná. Tais atividades foram expandidas a partir de um programa do Ministério do Desenvolvimento Agrário (MDA) em parceria com a ONG Anda Brasil, representante da Federação Internacional de Esportes Populares no país, que visa a capacitação de pessoas e o financiamento de caminhadas ecológicas. Atualmente, segundo dados da Anda Brasil e do MDA, por volta de 300 cidades promovem este tipo de atividade todo ano com a participação de mais de 400 mil pessoas. Trata-se de um evento capaz de articular uma série de agentes tais como Estado, ONGs, profissionais do turismo, caminhantes, associações, comunidades religiosas, evidenciando certa porosidade nas fronteiras entre o político, o ecológico, o religioso, etc.

Ao propor este tipo de problematização termino por situar-me como partícipe de um esforço mais amplo em compreender o modo pelo qual a ecologia, bem como os outros domínios da vida social, não se restringe aos espaços a ela reservado, mas se imiscui em práticas que numa primeira vista estão desencarnadas desta marcação eco, tal como a política. Neste sentido, a provocação de Goldman (2008) que anima pesquisadores em buscar a política onde ela não parece evidente, também encontra aqui seus efeitos. Ao mesmo tempo, o foco de meu interesse empírico, as caminhadas na Natureza promovidas pelo Estado, também permite a reflexão sobre como a constituição

\footnotetext{
2 O termo "ambientalização social” encontra certa ressonância com “ambientalização dos conflitos sociais” de José Sérgio Leite Lopes (2004). Contudo, o termo aqui empregado procura marcar que o interesse deste trabalho não é apenas os conflitos sociais que adquirem contornos ecológicos, como também a expansão de determinado ideário ecológico para diversas esferas.
} 
de práticas ecológicas podem ser compreendidas, por exemplo, como peregrinações secularizadas, subvertendo, mais uma vez, enquadramentos apriorísticos.

A expansão de determinado ideário ecológico, a partir da segunda metade do século XX, esteve atrelada a um conjunto de movimentos contraculturais, que reconheceram nas questões ambientais uma via de acesso às críticas antimodernas por eles produzidas. Na esteira de alguns analistas do campo ambiental (Ferry, 1994; Carvalho, 2002, 2009; Duarte, 2004), pode-se situar o romantismo como uma importante fonte de produção da sensibilidade ecológica, bem como de um tipo de engajamento político por ela promovida. Conforme sugerem tais autores, a recusa às normatizações do fazer político, a valorização do self, da autoconscientização como ação transformadora e da politização do cotidiano individual, são alguns dos elementos que caracterizam este legado romântico na postura política ecológica. Interessa, para a presente discussão, destacar que esta mudança no padrão de engajamento político transforma ações privadas e individuais como consumo de alimentos orgânicos, separação de lixo e reaproveitamento de materiais, em atos políticos por excelência.

Contudo, a crescente legitimação social das questões ambientais por meio da internalização de algumas demandas do ideário ecológico em instituições e movimentos sociais tem alterado este panorama. O ímpeto anti-institucional e de valorização do self que, a priori, pode ser reconhecido como tendo suas raízes românticas, é deslocado por discursividades que trazem à tona a necessidade de: elaboração de projetos como forma de manipulação do futuro, uma visão holística da realidade, a manutenção do planejamento como requisito fundamental e a concepção da humanidade como tendo um mesmo destino. A partir destes termos, pode-se questionar: como acomodar práticas políticas que se caracterizam, sobretudo, pela valorização da autonomia numa ação, como a caminhada ecológica, promovida pelo Estado? Como se dá a relação entre um projeto individual e um projeto coletivo, e até mesmo estatal, de um mundo ecologicamente sustentável? Como seguir concebendo a ecologia como ideal de autonomia e da autenticidade das escolhas individuais, em detrimento das instituições disciplinadoras, quando as próprias instituições passam a promover e rotinizar este ethos ecológico?

Vale destacar que a relevância atribuída a institucionalização desta prática como parte de um processo mais amplo de expansão de certa ética ecológica, resulta da concepção das caminhadas como objetificadoras de uma série de articulações que envolvem educadores ambientais, agentes estatais, agricultores, profissionais do 
turismo, etc. Neste sentido, a caminhada é um centro de enunciação capaz de produzir e promover uma série de discursos que podem pautar os núcleos em torno dos quais vai se definir o que seja o ecológico. Se, por um lado, podemos pensar que o discurso ecológico seja o lugar-comum dos sujeitos envolvidos nestas atividades, por outro, podemos nos questionar sobre as práticas, as disputas, os elementos distintos, e mesmo contraditórios, que são acionados nestes contextos. Interessa, para a presente discussão, o modo pelo qual esta série de disputas em torno do ecológico está associada com a produção de um espaço, de uma paisagem também ecológica. Isto é, de que maneira a articulação entre diferentes atores na promoção da caminhada está relacionada com a promoção/produção de uma paisagem “natural” especifica que marca a passagem de uma Natureza bruta para uma Natureza suficientemente pedagógica.

A partir deste horizonte de problematizações, detenho-me, em um primeiro momento, na tentativa de apresentar um breve panorama histórico das relações dos sujeitos com a Natureza tomando como fio condutor a prática de caminhadas. Isto é, de que modo a prática de atividades ao ar livre no período da revolução industrial, o turismo de massa do início do século XX, a emergência de movimentos de jovens protestantes tal como o escotismo e a caminhada como política estatal, estão balizadas por perspectivas distintas sobre a Natureza. E, noutro momento, procuro apresentar uma reflexão sobre a maneira pela qual a própria elaboração do percurso da caminhada e a experiência de percorrê-lo, para os caminhantes, está relacionada com determinada concepção de Natureza e do que seja ou não ecológico. Para tanto, concentro minha etnografia, e a discussão que a segue, na prática do espaço dos sujeitos que caminham e que planejam a caminhada, articulando noções como paisagens, espaço e tempo. Por fim, na conclusão elaboro uma reflexão sobre como discursividades globais e singularidades locais se articulam nas questões ambientais da caminhada, bem como, sobre a relação entre indivíduo e coletivo na incorporação de um ideário ecológico.

\section{“Uma querela doméstica”: por falar sobre tempo e a antropologia}

O lugar da reflexão sobre a dimensão temporal nas narrativas etnográficas e na produção antropológica tem ocupado uma posição instável na trajetória da disciplina. Em momentos iniciais, de delimitação das fronteiras daquilo que estaria ou não na alçada dos antropólogos, os paradigmas evolucionistas tornaram a modalidade temporal definidora do campo. A instauração de uma perspectiva diacrônica que avaliava os 
grupos sociais pesquisados a partir de uma série de nexos causais ascendentes, unilineares e irreversíveis, constituiu parte das características que permitiram a inserção do evolucionismo cultural no quadro mais amplo da economia da produção científica do final do século XIX. Todavia, a dificuldade metodológica de operacionalização da reconstituição histórica universal deslocou o lugar da história nas perspectivas culturalista e funcionalista, ambas críticas ao evolucionismo. No caso da primeira, a comparação deveria levar em conta, sobretudo, as singularidades de seu contexto de produção e, por isso, concebia Boas (2003), o recurso à história deveria estar circunscrito ao particular. Para Evans Pritchard (2005), que condensa algumas reflexões lançadas pela segunda perspectiva, a relação da antropologia com a diacronia constituía uma “querela doméstica” que não deveria tirar as sociedades contemporâneas do foco de atenção dos antropólogos, mas, tampouco, ignorar a história. A proposta de Pritchard deslocou uma noção de história como categoria universal, para uma categoria de tempo nativa, interna ao grupo.

No que se refere ao desenvolvimento das estratégias de construção da narrativa etnográfica, pode-se sugerir, conforme aponta Joahannes Fabian (1983), que embora o compartilhamento de tempo - coetaneidade - seja condição para a pesquisa etnográfica, o processo de textualização subverte esta condição utilizando categorias de “distanciamento temporal, colocando o autor do discurso num tempo diferente daqueles sobre os quais escreve” (Fabian, 2006: 510). Durante a segunda metade do século XX, o posicionamento de autores como Claude Levi-Strauss (1996), Marshall Sahlins (1997a) e Clifford Geertz (1978) colocaram à prova, atualizaram, propuseram outras perspectivas acerca destas tensões com a história. Não nos interessa aqui apresentar os posicionamentos de cada um deles ${ }^{3}$, mas apresentar a instabilidade do tratamento dado ao tempo e a história na produção antropológica. Trabalhos como o de Fabian (1983) têm ajudado a estabelecer alguns parâmetros críticos com relação ao modo pelo qual situamos e nos situamos diante do tempo dos Outros. Meu esforço, aqui, vai na mesma direção, não para tornar evidente a temporalidade dos Outros, mas para explicitar a dimensão temporal de uma relação Ocidental recoberta de aparente imunidade histórica, a saber, a relação Humano-Natureza. O que está em jogo é compartilhar propostas como as de Bruno Latour (1994, 2002) e de Eduardo Viveiros de Castro (2002) e reverter o eixo de reflexão da margem para o centro, dos Outros para Nós.

\footnotetext{
${ }^{3}$ Para uma discussão sobre história e antropologia ver: Schwacz (2005), Goldman (1999), Johannes (1983).
} 
Ao recorrer a este tipo de problematização para refletir sobre a promoção de caminhadas ecológicas como ação governamental, não estou buscando inserir esta atividade em uma grande narrativa de um trajeto único e definitivo da relação HumanoNatureza, mas apresentar o modo pelo qual esta narrativa é múltipla e capaz de ser acionada, por exemplo, tanto para se enfatizar o caráter libertário da Natureza, como seu potencial pedagógico ${ }^{4}$. Ademais, o esforço já referido em colapsar a perspectiva da dualidade cartesiana entre sujeito e objeto (Merleau-Ponty, 1994) tem como conseqüência a possibilidade de deixarmos de conceber a Natureza como ocupante de uma posição estática, inerte, a-temporal, para pensá-la como dinâmica, móvel e "historicizável”.

\section{Processos históricos da relação Humano-Natureza}

Ao menos no que se refere à Europa Ocidental, pode-se dizer que as relações estabelecidas com as montanhas estão associadas com uma série de transformações históricas entre Humano e Natureza ${ }^{5}$. As informações disponíveis sobre a percepção, durante a Idade Média, de como as montanhas eram concebidas estão dispersas. Trabalhos como os de Jouty (1991) e Majastre (1991) - que seguirei de perto nos próximos parágrafos -, no entanto, sistematizaram parte dos dados disponíveis sobre a temática e esclareceram-nos que a aparente invisibilidade das montanhas neste período está mais associada com uma atenção direcionada a determinados locais, do que a um ignorar por completo estas formações. Assim, se por um lado pouco são os registros sobre os Alpes e outras montanhas continentais, por outro, nos textos da Idade Média há uma profusão de referências aos montes Ararat, Sinai, Cáucaso, e Olimpo, bem como aos picos de Adão e Etna. Outro aspecto inicial importante para compreendermos como as transformações na relação Humano-Natureza estão relacionadas com mudanças nas práticas de atividades no "ar livre”, é o fato de que a altitude, na Idade Média, não era o parâmetro para a definição de montanha, mas sim o relevo. Por pelo menos duzentos anos, aponta Jouty (1991), discutiu-se com afinco se o mar era mais alto que o

\footnotetext{
${ }^{4}$ Meu próprio texto ocupa uma posição ambígua em que ao assumir a posição de intérprete do campo ambiental torna-se também parte deste mesmo campo como "interpretável”. A reflexão de Eckert e Rocha (2005) sobre o antropólogo como narrador também aponta nesta direção: “(...) uma vez ouvinte, o antropólogo imediatamente se torna, ele também, parte da coisa narrada” (pp.54)

${ }^{5}$ Destaco que não situo minha ênfase na modificação da sensibilidade dos sujeitos perante as montanhas, mas uma modificação na relação. Isto porque o que está em jogo não é um sujeito agente e um espaço passivo, mas concebo ambos como implicados.
} 
continente, o que demonstra a dificuldade que se tinha em quantificar altitude - algo que foi possível apenas na era moderna.

Se buscarmos as descrições do que seria o paraíso terrestre na Idade Média, este lugar é descrito sem muita variação, como a maior montanha da Terra (Thomas, 2010). A razão para esta associação, tão distinta daquela que o cristianismo moderno consolidaria são três (Jeuty, 1991). A primeira é, nos termos de Jeuty (1991), simbólica e se expressa, por exemplo, a partir da associação entre o céu e o lugar dos justos - tal como na obra “A Divina Comédia” de Dante. A segunda refere-se a inacessibilidade destes locais. Por fim, havia uma percepção de que os "ares” das montanhas trariam benefícios para a saúde dos indivíduos.

A partir deste contexto, pode-se perceber o modo pelo qual as montanhas carregavam uma sacralidade intrínseca, a qual ainda se somaria o fato de terem se constituído como lugares de peregrinação. Este panorama, no entanto, aos poucos foi se alterando. O advento do renascimento e a reforma protestante, somada a intensificação do interesse científico, de atividades esportivas e a associação destes locais com sensações como frio, altitude e ar rarefeito contribuíram para uma espécie de laicização das montanhas e, posteriormente, de “ressacralização”. Por um lado, o desenvolvimento de outras formas de explorar as montanhas, além das peregrinações, desencadeou um processo de “dessacralização” destes locais. Por outro lado, estas mesmas práticas contribuíram para recolocar a sacralidade das montanhas em termos da singularidade da paisagem e da existência de uma espécie de monumento natural.

Junto com as montanhas e, de algum modo associado a elas, o termalismo também foi fundamental para a promoção de atividades na Natureza que são efeitos e, ao mesmo tempo, agentes da transformação da relação com o ambiente. A presença de cachoeiras, lagos e águas termais nas montanhas, contribuíram para que se desenvolvesse, nestes locais, um dos primeiros tipos de turismo: o turismo de saúde. Acompanhando o texto de Majastre (1991), tomo como referência as experiências de Mointgne e Michelet para descrever a ascensão do termalismo como importante no horizonte de transformações históricas da relação Humano-Natureza.

A prática de buscar, em águas termais, uma fonte de benefícios para a saúde contribuíram para situar o corpo como principal testemunha das sensações com a Natureza. Mointagne realizou diversas viagens pela Europa na busca pela melhor terma, pela melhor dosagem de água a ser despejada sob o corpo e pelas partes do corpo em 
que a aquisição de benefícios se daria mais rapidamente ${ }^{6}$. Michelet, por sua vez, dedicou-se na divulgação de suas idéias sobre a Natureza como regeneradora da vida. Para ele, os corpos Humanos estavam engajados como filhos e amantes da Terra, obtendo mais simbiose não a partir dos banhos, mas a partir dos odores que poderiam ser obtidos em espaços como as termas.

Especialmente na França, as casas de banho se popularizaram e oscilaram em um curto período de tempo entre uma prática limitada à nobreza e a atividades de massa. O tratamento médico a partir das águas - que durava vinte e um dias -, passou a ser dificilmente realizado por conta da extensa jornada de trabalho e as casas de banho deixaram de ter uma conotação relacionada com a obtenção de saúde para serem associadas a um lugar de jogos de azar e prostituição. De qualquer modo, o que estes processos apontam é para a dinamicidade das relações e atividades promovidas em ambientes naturais antes do século XVIII. Dando um salto histórico considerável, passo agora a uma transformação contemporânea que contribui para a expansão de atividades na Natureza, a saber, os acampamentos.

Na França, a prática de campings foi introduzida por uma associação nos anos de 1900 que organizava acampamentos para jovens protestantes. Uma série de atributos morais foi dada ao acampamento, tais como: respeito à Natureza, celebração dos esforços individuais e da solidariedade do grupo, elogio à Natureza, independência, autonomia, senso de responsabilidade e de coletividade. A emergência da prática do camping está associada à ascensão de uma nova burguesia e a exaltação das coletividades dadas pela guerra (Lavenir, 2001).

A associação protestante citada editava uma revista que teve alta circulação no início do século XX promovendo não apenas o camping, como também o ciclismo. A difusão destas práticas para o contexto anglo-saxão deu-se, em alguma medida, por meio do escotismo, movimento surgido na Inglaterra. No entanto, segundo Lavenir (2001), foi a partir do envolvimento de alguns políticos protestantes com o grupo de acampamento francês que a prática ganhou apoio do poder público e se popularizou na Europa.

O camping tinha, nas décadas entre 1900 e 1920, um caráter de explícito proselitismo e de disciplinamento militar. Por um lado, caracterizava-se pelo isolamento e pela aproximação a uma Natureza que permitisse viver de modo independente, por

\footnotetext{
${ }^{6}$ De algum modo o debate sobre Natureza e Cultura atual tem conduzido antropólogos a colocarem no centro de suas reflexões o corpo. Sobre esta relação temática, ver Descola (1996)
} 
outro, conduzia ao elogio de formas de deslocamentos mediadas apenas pelo corpo, tais como caminhadas, ciclismo e canoismo. Em 1914, o governo francês organizou um camping fixo, freqüentado por grupos distintos e com interesses diversos no contato com a Natureza. Os jovens protestantes destacavam a aquisição de responsabilidades, o exercício do altruísmo e a educação coletiva como os principais benefícios da atividade. Os adultos alegavam que a experiência do acampamento, tanto contribuía para o aprendizado do convívio em grupo, como enfatizavam as benesses do isolamento temporário (Lavenir, 2001; Baubérot, 2001).

Com o tempo, especialmente no entre guerras, o camping deixou de ser associado ao isolamento, educação e altruísmo, passando a ser concebido como um “hotel ao ar livre”. Após a Segunda Guerra, a prática do camping adquiriu novas conotações e passou a ser associada com a ruptura de hábitos mundanos, o que permitiria uma espécie de purificação dos “vícios da civilização” e de ascese corporal.

O que está em jogo na construção deste breve relato histórico das transformações das atividades na Natureza é apresentar o caráter dinâmico desta relação, bem como os múltiplos sentidos que foram sendo atribuídos a elas e como estas concepções estão relacionadas com o florescimento de determinadas práticas. Este recorte histórico apresenta um conjunto de contextos de práticas que explicitam que não se trata de uma natureza, mas de muitas naturezas apreendidas ao longo de um extenso período de tempo ${ }^{7}$. Com isso, não pretendo simplesmente apresentar em que momento histórico está situada a promoção governamental da prática de caminhadas ecológicas, mas, antes disso, reafirmar que este tipo de atividade diz algo sobre a própria relação Humano-Natureza que está sendo estabelecida.

A elaboração da narrativa etnográfica a seguir privilegia tanto as articulações institucionais que são mobilizadas para que a caminhada seja possível, como também aponta para o estabelecimento de relações diversas com o ambiente promovidas pela

\footnotetext{
${ }^{7}$ Neste sentido, vale o esforço de inverter o endereçamento da pergunta "que Natureza é essa da caminhada ecológica” - antes destinada apenas aos partícipes de meu universo de investigação - para voltá-la ao próprio modo pelo qual denomino a prática observada, caminhadas na natureza. O que está em jogo é deixar de direcionar meu esforço reflexivo apenas para apontar que aquela Natureza, aparentemente atemporal, buscada pelos caminhantes e pelos promotores da caminhanda é historicizável, para desconfiar também de minhas próprias formulações. Isto é, ao mesmo tempo em que procuro apontar para as distintas apropriações da Natureza escancarando um fluxo, uma dinâmica histórica que fuja de uma apreensão genérica, caio numa armadilha lingüística que reduz e singulariza o local em que ocorre a caminhada chamando-o genericamente de na natureza. A proposta de acomodar a percepção da Natureza em um contexto mais amplo, conduz a repensar os limites que um desígnio como "caminhada na Natureza" me impõe. Por isso, quando referir-me as caminhadas "na Natureza" que observo colocarei o termo Natureza entre aspas no intuito de afirmar que sua pluralidade não pode ser expressa no singular.
} 
caminhada. Para esta discussão, tomo como fio condutor o modo pelo qual os distintos modos de conceber o espaço implicam em sentidos distintos de Natureza.

\section{Da fertilidade à beleza: caminhadas na natureza como projeto de Estado}

A cidade de Ivaiporã está situada na região central do Paraná, distando 400 quilômetros da capital Curitiba. Na primeira metade do século XX, esta localidade foi um dos principais centros de produção de café do país, chegando a ter oitenta mil habitantes. Atualmente, embora a principal atividade econômica siga sendo a agricultura, o número de habitantes é de trinta e cinco mil e a monocultura do café deu lugar a agricultura familiar e às culturas de trigo, aveia e criação de bicho-da-seda. A promoção da Caminhada Internacional na Natureza de Ivaiporã resultou de um esforço conjunto que mobilizou as três instâncias do poder público: a prefeitura - a partir do envolvimento das secretarias na operacionalização da caminhada -, o governo do Estado - a partir do apoio da EMATER e outros órgãos voltados ao desenvolvimento rural -, e o MDA - a partir de diversos projetos que têm as caminhadas "na natureza" como atividade prevista. Se a articulação de agentes heterogêneos em torno desta atividade no interior do Paraná foi o que possibilitou sua realização, a eleição desta prática como projeto governamental deriva da ONG Anda Brasil, representante do país da Federação Internacional de Esportes Populares. Esta ONG, fundada em 2006, tem uma função dupla na promoção de caminhadas. Por um lado, realiza oficinas de capacitação para que agentes municipais, secretários das prefeituras, turismólogos, etc., possam elaborar circuitos de caminhadas conforme os padrões internacionais ${ }^{8}$, por outro, dar apoio e fornecer uma série de materiais durante a preparação e execução das atividades. As prefeituras, por sua vez, entram em contato com a Anda Brasil ou pela participação de algum funcionário nas oficinas da ONG ou pela adesão do município a projetos estaduais e federais.

O Paraná tem se destacado como um dos principais Estados em que há promoção de caminhadas “na natureza” elaborando, inclusive, um projeto chamado “Caminhadas no Paraná”9 . No caso de Ivaiporã e da região em que está localizada a cidade, especificamente, foi Ivaldete, uma técnica local da EMATER - Empresa de

\footnotetext{
${ }^{8}$ Estes padrões referem-se, basicamente, a sinalização, distância percorrida e quantidade de postos de parada por quilômetro caminhado.

${ }^{9}$ Este projeto foi criado no âmbito da secretaria de agricultura do Estado e é apoiada pela rede TRAF (Turismo Rural na Agricultura Familiar) do Ministério de Desenvolvimento Agrário.
} 
Assistência Técnica e Extensão Rural - quem tomou contato e mobilizou a prefeitura para a realização da atividade.

Em 2007 eu fui fazer um treinamento sobre trilhas em Caxias do Sul, lá na Estrada dos Imigrantes. E esse curso foi pago pelo MDA. Aí foi convidado o Violento, que é o presidente da Anda Brasil , e foi convidado para estar lá e acompanhar todo o curso. O Violento deu uma palestra e em meia hora falou sobre o que eram as caminhadas. Quando ele falava, eu imaginava a nossa região, imaginava como poderia ser aquilo aqui. Aí ele falou que teríamos em setembro de 2007, em Curitiba, uma oficina de caminhadas. Aí eu não podia ir, e também outra coisa, eu vi assim, eu estava lá em Caxias, eu não posso ir em tudo, tenho que colocar outras pessoas para aprender. Aí eu liguei para as meninas do grupo que coordeno e pedi para três delas, duas técnicas sociais e uma veterinária, irem para essa capacitação em Curitiba. Quando elas voltaram, sentamos nós quatro e elas já voltaram com dois caminhos já traçados, que foi Manoel Ribas, onde tem o Santuário da Nossa Senhora da Salete e o de Lunardelli. (Ivaldete)

A narrativa de Ivaldete sobre a constituição de um circuito de caminhadas que abrange diversas cidades da região central do Paraná, a com maior concentração rural do Estado, nos auxilia a compreender tanto o caráter destas atividades, como também o modo pelo qual estes eventos apresentaram-se como distintos do tipo de assistência que órgãos como a EMATER prestavam. A este aspecto detenho-me a seguir.

\section{Mudando de foco: da assistência técnica agrícola para o turismo rural}

Políticas ambientais estão na pauta governamental brasileira ao menos desde a década de 1970. Esta agenda política, entretanto, esteve balizada, em um primeiro momento, por agências de governança global como a ONU. Posteriormente, legislações ambientais foram criadas para contemplar exigências de credores internacionais como BID e $\mathrm{FMI}^{10}$. Assim, o desenvolvimento de ações governamentais referentes às questões ambientais pautou-se, neste período, em diretrizes internacionais. Grosso modo, estas ações diziam respeito, sobretudo, ao manejo de espaços, seja pela atenção aos lugares de conservação, seja pela maior assistência dos espaços de produção agrícola. Compreender estes tipos de gestão da Natureza nos ajuda a compreender o que atividades como caminhadas "na natureza” estão relacionadas com formas específicas de conceber estas paisagens.

Os projetos de criação de unidades de conservação ambiental, parques, santuários ambientais, etc., não estiveram, inicialmente, relacionados com uma intenção

\footnotetext{
${ }^{10}$ Esta relação também pode ser observada em outros países em desenvolvimento, tal como mostra Fátima Chaves no caso do Paraguai (2004).
} 
de exploração turística destes locais, mas associados com a idéia de proteção e de preservação da área da ação antrópica. Este modelo de parques, importado dos Estados Unidos, não privilegiava a interação entre um espaço protegido e Humanos, mas isolava, criava ilhas em que uma Natureza supostamente autêntica poderia seguir seu curso longe daqueles que poderiam descaracterizá-la por sua presença ${ }^{11}$. Entretanto, a Natureza preservada nestes espaços não é anterior a criação das unidades, mas está relacionada com a emergência de um modelo explicativo capaz de descrevê-la enquanto unidade de conservação autêntica e que merece ser preservada. Como aponta Godoy (2000):

Trata-se de definir a Natureza criando a explicação científica que a certifica e que, tornada autônoma, converte-se em medida da Natureza o "objeto" cuja circulação representa o coletivo de cientistas que o havia inventado. Tais Naturezas não antecedem os procedimentos que as tornam visíveis. Não estando lá desde sempre, descobri-las é tanto criá-las quanto torná-las efetivas, isto é, sua potência enquanto invenção científica traduz-se precisamente no interesse que são capazes de despertar em outros grupos, e sua duração está associada à possibilidade de ser compartilhada por diferentes indivíduos e coletivos, construindo outros domínios, produzindo outras tecnologias. (Godoy,2000:132)

O que a autora salienta é que não é a lei que determina a criação das unidades de conservação, mas as unidades emergem das próprias leis. No caso da criação das unidades, cabe ao Estado e a Ciência determinar qual Natureza precisa ou não ser preservada, estes critérios, no entanto, são referenciados como fatos reais, autônomos dos processos de determinação Humanos.

As Unidades de Conservação apresentam-se como o modo de operar da Ecologia sobre territórios que ela estabelece a partir da definição de seu próprio território científico, onde cada lugar, cada área, é reportada a um modelo simultaneamente científico (classificação, hierarquização) e natural, pois o critério utilizado para a criação das áreas - a diversidade - seria dado pela Natureza. (Godoy, 2000:134)

Além da criação de unidades de conservação, as ações governamentais concentravam-se no manejo de terras agriculturáveis e na assistência técnica aos produtores. Se a Natureza das unidades de conservação era aquela em que a presença humana provocaria sua degradação, no caso das terras de agricultura, a Natureza deveria ser manipulada para que sua fertilidade fosse maximizada. Organismos especializados

${ }^{11}$ Para uma discussão sobre a criação de unidades de conservação ambiental e parques, ver Godoy (1999), Barreto Filho (2001), Pádua (1987) 
como a EMATER foram criados e deram apoio ao trabalho técnico das secretarias de agricultura estaduais.

No caso pesquisado, o da I Caminhada Internacional na Natureza de Ivaiporã, a EMATER foi uma das principais articuladoras da atividade, colocando em relação instâncias municipais, estaduais e federais. Este tipo de atividade, entretanto, pode ser compreendida como demarcadora de uma virada no foco das ações governamentais. As caminhadas "na natureza" não ocorrem em parques ou unidades de conservação, mas passam em propriedades rurais, com a maior parte do percurso entre plantações. O que está em jogo não é uma atividade em uma suposta Natureza autêntica, tampouco uma política de assistência técnica aos trabalhadores do campo, mas a promoção de uma atividade voltada aos citadinos, uma ode a um tipo de natureza não detentora, a priori, do direito de ser preservada.

Ivaldete, ao narrar sua trajetória de vida aponta para este deslocamento de parte do trabalho da EMATER:

Nós da EMATER sempre trabalhamos com assistência técnica do agricultor, mas era muito direcionada só para agricultura. Daí realmente de 80 para cá houve uma mudança preocupada não só com a renda agrícola, mas preocupada também com a renda não agrícola. Como nós falamos, preocupada em transformar o produto e comercializar o produto né. $\mathrm{E}$ o turismo é isso, né. É você trabalhar a questão do artesanato, hoje nós trabalhamos muito o artesanato em fibra de bananeira, em bambu, taboa. A gente trabalha muito o artesanato hoje nessa linha de fazer com que as pessoas não trabalhem só a produção, mas também o outro lado, que ela veja a propriedade com outro olho usando também essa outra alternativa. (...) Caminhada não é para quem está no meio rural, é para quem está na cidade. Quem tá no meio também vai, mas principalmente quem está no meio urbano é que vai caminhar, porque ele precisa caminhar, ver, distrair a cabeça. E nosso objetivo é levar o do meio urbano para o meio rural, para ele conhecer. Eu vou te dizer, a maioria que vai amanhã na nossa caminhada que é daqui da cidade não conhece o meio rural. Então é uma forma de conhecer e esse contato com o produtor eu acho muito importante. (Ivaldete)

A possibilidade de haver investimento no desenvolvimento rural não voltado à produção agrícola não se deu sem conflitos. O foco no turismo rural, por exemplo, poderia colocar em questão, para alguns movimentos sociais, a necessidade de reforma agrária no país. De todo modo, a diversificação das atividades econômicas no campo constitui, para as agências governamentais, um dos principais atrativos de práticas como caminhadas "na natureza”. Tornar os campos de lavoura paisagens turísticas, no entanto, demanda a elaboração de um percurso, construção de dispositivos e uma série de equipamentos que permitam a efetivação deste projeto. 


\section{A invenção do lugar turístico: a preparação e a caminhada}

Após chegar a Curitiba na sexta-feira, esperar por cinco horas o único ônibus da capital com destino a Ivaiporã e viajar por mais sete horas pelo interior do Paraná desembarquei na cidade. Já no deslocamento da rodoviária para o hotel percebi muitas faixas espalhadas pelas ruas anunciando a caminhada, na porta e na recepção de onde me hospedaria havia cartazes e folders de divulgação, além de uma moto com altofalante na garupa dando voltas no centro convocando a todos para atividade. Pela manhã de sábado encontrei-me com Ivaldete, uma das coordenadoras do evento, e seguimos para o local em que começaria a caminhada. Neste trajeto, Ivaldete foi me mostrando o que já haviam feito: pendurado faixas com os dizeres "I Caminhada Internacional da Natureza de Ivaiporã”, pintado grandes setas brancas no asfalto que indicariam o caminho para os ônibus que seguiriam até o local onde a caminhada teria início, espalhado lixeiras no trajeto e colocado setas indicativas nas trilhas.
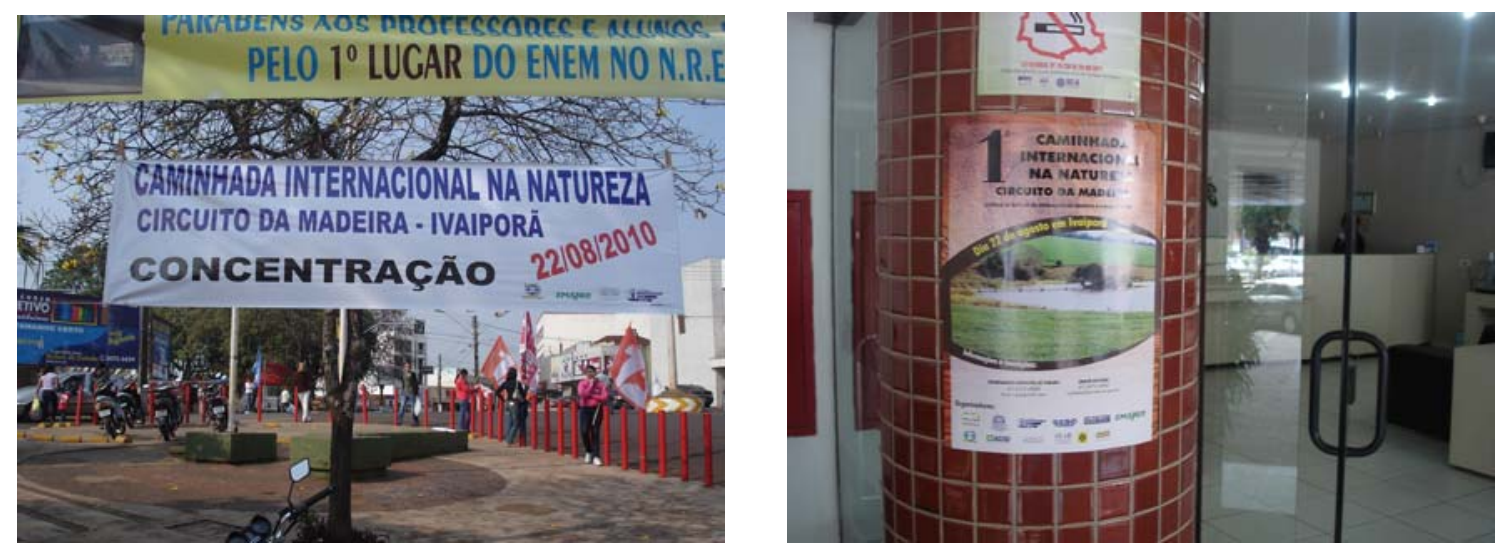

Conforme Ivaldete narrava o que já havia sido feito também apresentava os agentes locais envolvidos na caminhada. Todas as secretarias da prefeitura haviam sido mobilizadas: a da saúde disponibilizou pessoal e ambulâncias para acompanhar a caminhada, a da educação fez da colocação de faixas, lixeiras e setas no trajeto uma atividade obrigatória dos estudantes do curso de técnico em meio ambiente, a da indústria e comércio recolheu doação de brindes dos comerciantes da região para serem sorteados no final da atividade, etc.

Esta série de articulações que evidenciam a intencionalidade de criar um ambiente preparado para receber turistas e interessados no evento ${ }_{2}$ aponta para o aparente paradoxo de uma atividade que introduz a questão ambiental na pauta das 
políticas públicas municipais via a necessidade de desenvolvimento das regiões rurais e da exploração das múltiplas potencialidades da agricultura familiar local.

Este ambiente que se faz presente ao longo do trajeto da caminhada, no entanto, não é o mesmo que das unidades de conservação, como afirma Ivaldete: "O que vai acontecer aqui não uma caminhada ecológica, mas uma caminhada na Natureza. Isso porque não é uma caminhada que só passa no meio do mato, mas que passa por propriedades rurais.”

A inscrição na caminhada é gratuita, apenas o café da manhã - quatro reais - e almoço - dez reais - são cobrados, mas opcionais. O local de início da atividade era distante do centro da cidade e, por isso, a prefeitura cedeu toda sua frota de ônibus para a realização do transporte dos caminhantes da praça central para o local de início do trajeto. Além dos caminhantes da própria cidade e daqueles que se deslocaram por conta própria, sete prefeituras disponibilizaram ônibus para que seus moradores também participassem do evento. Todos os municípios que cederam transporte a seus habitantes também promovem caminhadas "na Natureza”, o que sugere o estabelecimento de um compromisso de recíproca neste apoio.

Acompanhando Ivaldete em sua última "vistoria” dos preparativos da caminhada que ocorreria no dia seguinte, paramos na casa de Seu Ivo, um dos pontos atrativos da caminhada. Esta era uma propriedade ampla e que não tinha como principal atividade a agricultura, mas a produção de móveis em madeira rústica. Por conta desta propriedade e de outras duas que o trajeto da caminhada também passaria, ambas igualmente produtoras de móveis em madeira, a caminhada recebeu o nome de Circuito da Madeira. A denominação do trajeto é, segundo Ivaldete, um elemento importante na caracterização da atividade e na atribuição de uma identidade específica à região.
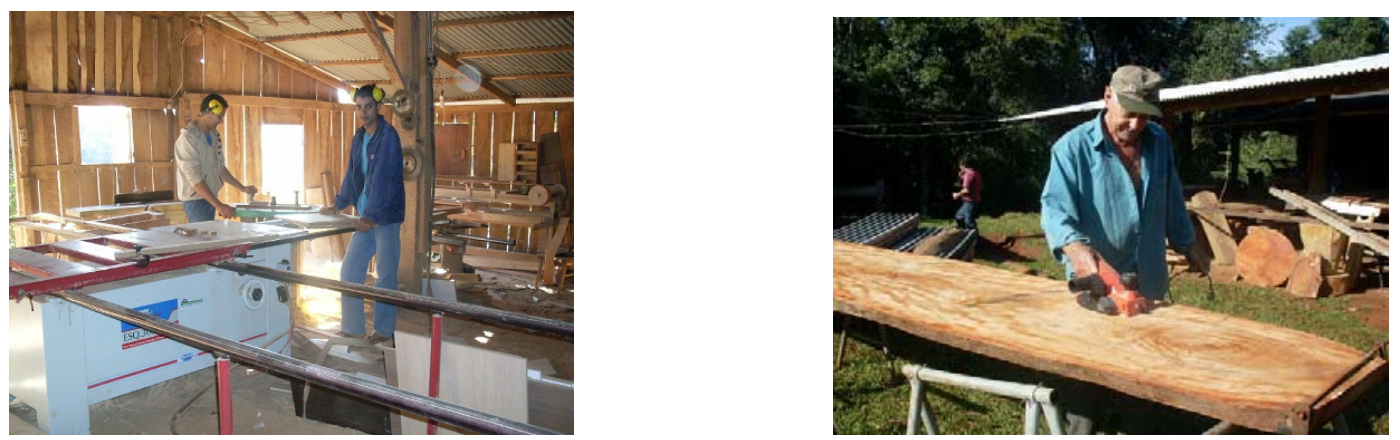

Além de colocar à mostra diversos móveis produzidos em sua propriedade, Seu Ivo colocou placas em cada objeto que remetia a "vida no campo", tais como "abelha jataí”, “alambique”, “monjolo”, “descascador de arroz”. Havia certo clima de apreensão 
por parte do Seu Ivo que, em um dado momento de nossa visita, perguntou a Ivaldete: “Você acha que vai vir alguém?”. Mesmo já sabendo que havia mais de 300 inscritos, a resposta de Ivaldete foi evasiva.

Saímos desta fazenda e fomos até a casa de Dirce, a secretária de indústria e comércio da cidade, ponto em que seria servido o café da manhã e local de onde a caminhada teria início. Dirce tem uma singularidade política, seu cargo não deriva de uma indicação do prefeito, mas dos comerciantes de Ivaiporã, o que dá a ela uma grande visibilidade e aceitação entre as pessoas da cidade. Durante a entrevista com Ivaldete, um dia antes da caminhada, perguntei a ela a que atribuía uma adesão tão grande àquela atividade: “somos boas marqueteiras [referindo-se a ela e a Dirce], o pessoal aqui respeita a EMATER e a Dirce teve todo o apoio dos comerciantes, sem ela não conseguiríamos arrecadar tantos brindes também” (Ivaldete).

Na casa de Dirce havia uma grande concentração de pessoas separadas em “grupos de trabalho”. O pároco da cidade, e também secretário de educação, coordenava uma equipe de três pessoas, a qual eu também auxiliei, que separavam os passaportes da caminhada $^{12}$. Outra “equipe”, coordenada por Dirce, organizava as frutas, bolos, cucas e pães que seriam servidos no café da manhã. Uma última conferia a sinalização ao longo do trajeto e preparava as dez placas referentes aos dez mandamentos da Natureza, elaborados por um padre da região.

Eu e Ivaldete ainda precisávamos verificar como estavam os preparativos na comunidade que recepcionaria os caminhantes na chegada e que ficara incumbida de preparar o almoço. Como estávamos nos dirigindo para o final do trajeto, ficamos encarregados de colocar o décimo mandamento - "Assumir compromissos na sociedade em favor do meio ambiente" - na marca do último dos onze quilômetros de caminhada.

Pouco antes de chegarmos à comunidade, nos encontramos com integrantes de um CTG - Centro de Tradições Gaúchas - que estava finalizando os preparativos para o dia seguinte, quando se apresentariam aos caminhantes no quilômetro nove.

Assim que chegamos à comunidade percebemos a grande movimentação. Alguns se concentravam na finalização da limpeza do terreno, outros na construção de uma gruta que abrigaria uma imagem de Nossa Senhora de Fátima. Parte das mulheres estava na cozinha preparando porções de purê de mandioca e parte dos homens assando

\footnotetext{
12 Trata-se de uma caderneta com quatro retângulos que seriam carimbados em pontos diferentes do trajeto, caso o caminhante obtivesse todos os carimbos receberia um certificado e outra caderneta, com o texto em francês e fornecida pela Federação Francesa de Esportes Populares, com um adesivo referente à caminhada de Ivaiporã e com espaços para adesivos de futuras caminhadas
} 
os 250 quilos de carne de porco e mais 200 quilos de galinha caipira. Além destes grupos, uma turma de senhoras, apoiadas pelo SESC, montava um toldo sob o qual exporiam seus artesanatos.

A articulação entre os agentes envolvidos na promoção da caminhada e as instâncias políticas está além da mobilização de alguns funcionários municipais. Ivaldete, uma das principais promotoras da caminhada, é amiga pessoal e foi assessora de finanças da campanha do atual governador do Paraná. Na noite que antecedeu a caminhada, Ivaldete e Marcos, seu esposo, me "intimaram” a comparecer a um jantar na casa do secretário da saúde do Estado, onde também estariam outros políticos de alcance estadual. Segundo Ivaldete, minha presença mostraria que o projeto das caminhadas “está rendendo frutos e visibilidade”.

O início do transporte dos caminhantes até o local de onde partiria a caminhada estava previsto para as 7 horas. Por volta das 7:40h, a praça estava cheia. Muitas famílias, estudantes de ensino médio uniformizados, grupos de terceira idade, casais de namorados, alguns trajando roupas destinadas a práticas esportivas e calçados adequados e outros, como pude ouvir mais de um comentário, “com roupa de missa, não de caminhada”.

Conforme os ônibus iam lotando, saiam para o local de início da caminhada. Como Ivaldete já havia me dito, havia um protocolo de boas vindas que foi lido por um dos organizadores na frente dos ônibus, momentos antes de eles começarem a se deslocar. Uma vez na casa de Dirce, os caminhantes dividiam-se em duas filas: uma para os já inscritos - aqueles que tiveram acesso, na casa do artesão, a um folder com um formulário e já haviam preenchido - e outra para os não inscritos. Caso quisessem comprar o ticket do café e do almoço, outra fila deveria ser enfrentada. A cada três minutos novos ônibus chegavam e, depois que todos desciam, o ônibus voltava para pegar mais pessoas no centro da cidade. A expectativa de trezentas pessoas foi superada apenas trinta minutos depois do primeiro ônibus chegar ao local de início da caminhada.

Ainda na fila, Mauro, um técnico da EMATER de outra cidade, veio falar comigo sobre a pesquisa. Perguntado sobre qual era o interesse de estar ali, Mauro disse que sua presença era um pedido dos prefeitos da região em que trabalhava para que buscasse, naquela experiência, algumas outras possibilidades de explorar as potencialidades da agricultura familiar para além da produção agrícola.

Enquanto eu e Mauro tomávamos o café, a imprensa local tirava fotos e entrevistava os caminhantes de fora do município - inclusive eu, entrevistado na 
condição de antropólogo e, supostamente, especialista no assunto. Antes de a caminhada começar formou-se um palanque de autoridades, improvisado em cima de uma carroça engatada em um trator. Além de um chefe de cerimônias, subiram no palanque o prefeito, o presidente da Câmara de vereadores, a coordenadora da EMATER, a presidente da câmara das mulheres empreendedoras de Ivaiporã, a secretária da indústria e comércio, o secretário de educação e pároco da cidade e um representante do governo do Estado. Segue um trecho das falas que compuseram este ato que durou mais de vinte e cinco minutos:

Dirce, secretária de indústria e comércio de Ivaiporã: "Em janeiro deste ano o prefeito e o Padre Geraldino foram na caminhada em Lunardelli e quando voltaram me chamaram: "Nadir, temos que fazer a caminhada em Ivaiporã”. Aí então, minha amiga Ivaldete, companheira, EMATER, que está aqui: "Vamos Nadir?", "Vamos!" e fizemos com a cooperação de todos. Não foi só EMATER, não foi só município, foi todos os departamentos do município, diretores, nem posso estar citando nomes que se não vou esquecer de alguém, agricultura, meio ambiente, obras, todos! Educação, todos! Saúde, todos! E o comércio gente? Até me emociono um pouquinho. O comércio de Ivaiporã ficou unido, muito obrigada. E os agricultores rurais, a comunidade? Ontem saí de Pindalvinha era dez horas da noite e o pessoal trabalhando das oito da manhã até às dez e pouquinho. A comunidade Água da Laranjeira, Água do milagre, comunidade de Pindalvinha... Então essa caminhada pra mim gente... essa noite, Ivaldete, eu entendi realmente o que é uma caminhada. Caminhada é amizade, é colaboração, é parceria. Gente, só tenho que agradecer a Deus e também a minha família que até pousaram comigo aqui. Só conseguimos realizar um trabalho porque a gente tem parceiros, meus pais que estão aqui trabalhando, incansavelmente, toda minha família me dando apoio. Meus filhos que estão longe, mas todo dia: "Mãe, como que está a organização da caminhada?”. Também a imprensa que está colaborando na divulgação, a todos, gente. $\mathrm{E}$ a vocês, não há caminhada sem os caminhantes. Os secretários de turismo de todos os municípios do vale do Ivaí organizados, a EMATER, é uma mobilização geral. Muito obrigado gente, que Deus abençoe a nós todos [aplausos].”

Apresentador: "Muito Obrigado Nadir. E agora passamos a palavra ao representante do governo do Estado do Paraná e também chefe regional da SEAB, senhor Antônio Esgobero [aplausos]”

Antônio Esgobero: "Bom dia pessoal em nome do governo do Estado do Paraná a gente dá as boas vindas a todos vocês (...) Eu gostaria, em nome do governo do Estado, de parabenizar duas pessoas, que são essas duas meninas aqui, a Ivaldete e a Nadir que, como já falaram aqui, vestiram a camisa e conseguiram criar a nossa primeira caminhada aqui de Ivaiporã (...) [aplausos]”

Apresentador: "Agora, com a palavra o prefeito da primeira caminhada da Natureza circuito da madeira, o prefeito Ciro Fernandes Correa Junior [aplausos]”.

Ciro Fernandes Correa Junior: "Bom dia a todos e a todas. Bem rapidinho, uma historiazinha. Vou lembrar de alguns que participaram para que estivesse ocorrendo esta caminhada. Quero deixar um abraço pro pessoal do curso de técnico ambiental do colégio Barbosa Ferraz. Logo que se passaram as eleições, eu fui a uma reunião 
no Barbosa Ferraz [neste momento um dos caminhantes grita o nome de Ivaldete] e lá nos foi solicitado que nós realizássemos a caminhada em Ivaiporã. Hoje, com a graça de Deus, com o trabalho da nossa secretária Nadir, o trabalho da Ivaldete em uma parceria entre prefeitura e governo do Estado a caminhada está acontecendo. Deus abençoe e que nós possamos fazer outras. Estes dias eu desafiei o pessoal da comunidade do Jacutinga a fazerem uma caminhada. Isso para que a gente tenha várias ao longo do ano. Esse é um programa bonito para se ir com a família, com os filhos, para as pessoas saírem da agitação da cidade e andarem pelo campo [aplausos]”.

Após esta fala e as instruções sobre a caminhada de Ivaldete, Padre Geraldino, que também é secretário de educação da cidade, conduziu um "Pai Nosso” rezado pelos surpreendentes mil caminhantes em voz alta.

A visibilidade dada ao papel de Dirce, secretária de indústria e comércio, e de Ivaldete na promoção do evento não está desconectada de outros domínios da vida pública da cidade. Se, nos próprios órgãos de assistência aos agricultores este tipo de atividade é visto com desconfiança por conta da "perda de foco" - a agricultura -, o contexto político local também é transformado por estes eventos. Este aspecto pôde ser percebido, por exemplo, ao final da caminhada quando o assessor do prefeito dizia a ele: "mas prefeito, você apareceu muito pouco. Agora a Dirce e a Ivaldete levar todo o mérito? E a prefeitura? Não tem faixas e nem nada? A Dirce? A Ivaldete?” E o prefeito - que também caminhou - com um semblante pensativo lamentou: "não pensei politicamente um evento que é político”.

Assim que terminaram os discursos no palanque - já sob a impaciência dos caminhantes -, um professor de educação física do SESC - foi dado ênfase a este pertencimento -, iniciou os exercícios de alongamento. Terminados os exercícios, a caminhada teve início. O ritmo das passadas nos primeiros metros dos onze quilômetros a serem percorridos era bastante lento, mas nada que parecesse entediar muito os caminhantes. Parte deles tocava violão e cantava Legião Urbana, outro grupo se espremia para pegar um chapéu que estava sendo distribuído, algumas senhoras caminhavam juntas e vestiam uma camiseta com os dizeres "grupo de caminhada da terceira idade” e eu focava minha atenção na primeira das dez placas dos mandamentos da Natureza: “Amar a Natureza como a si mesmo”. 

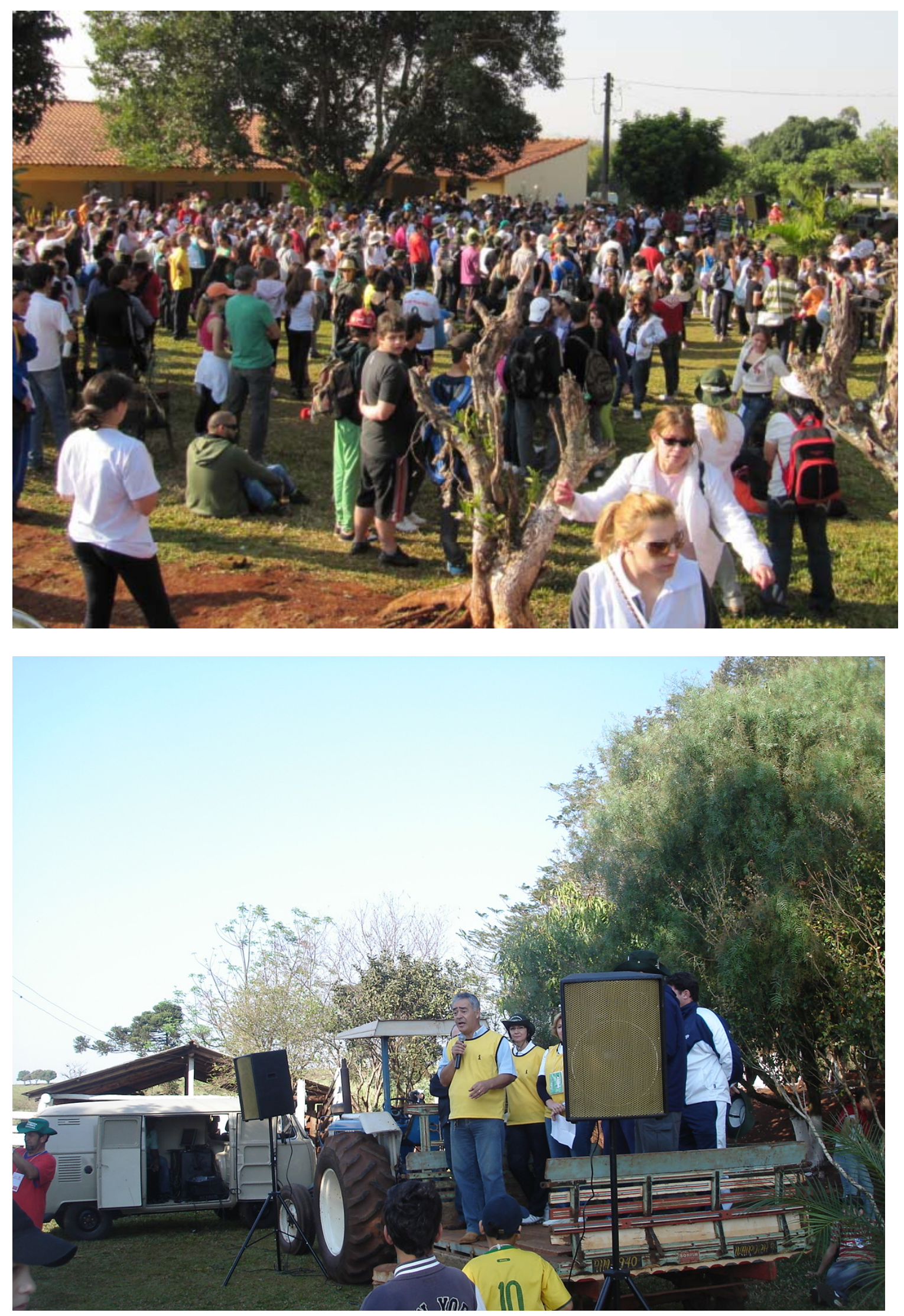

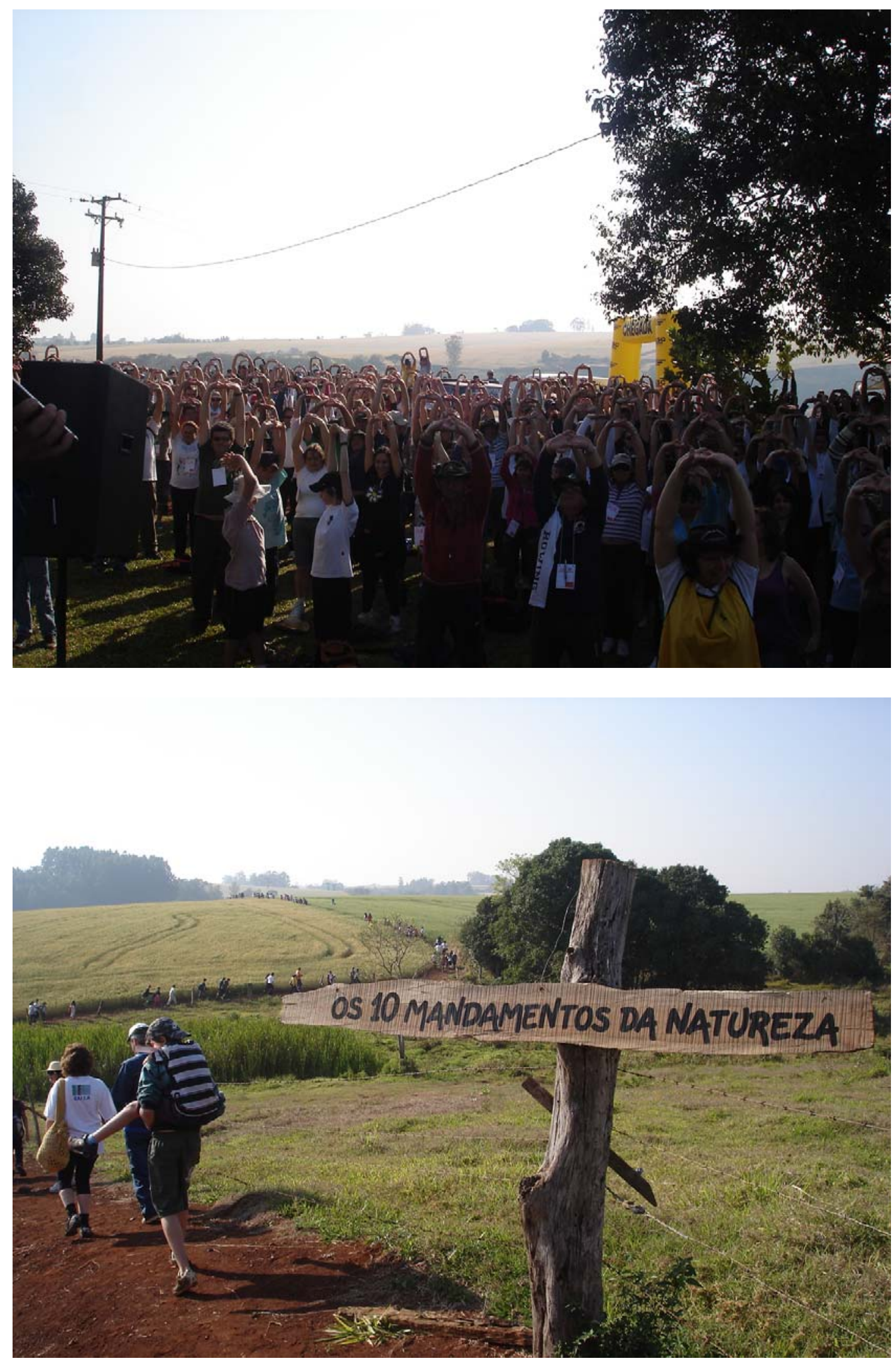

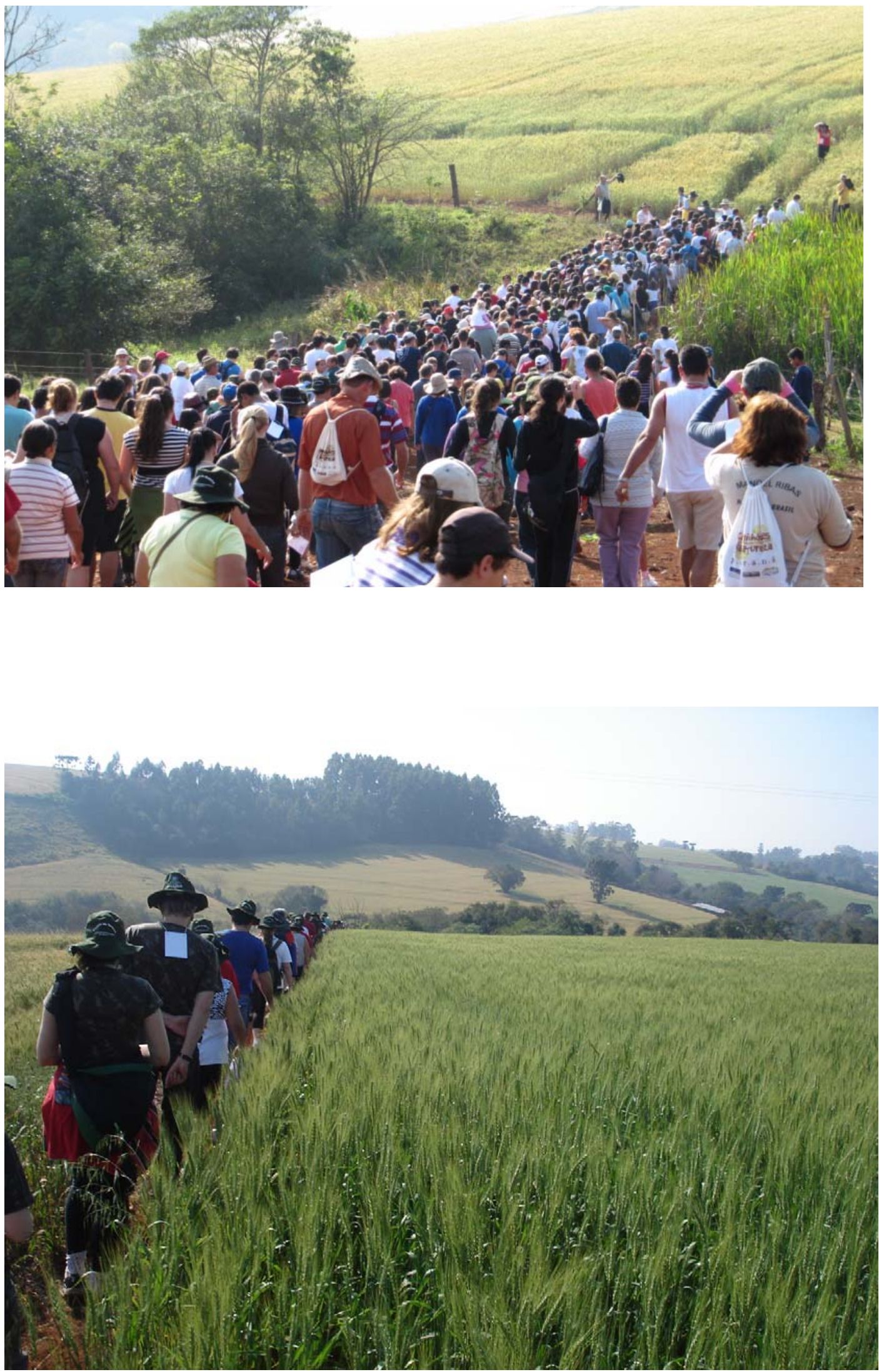


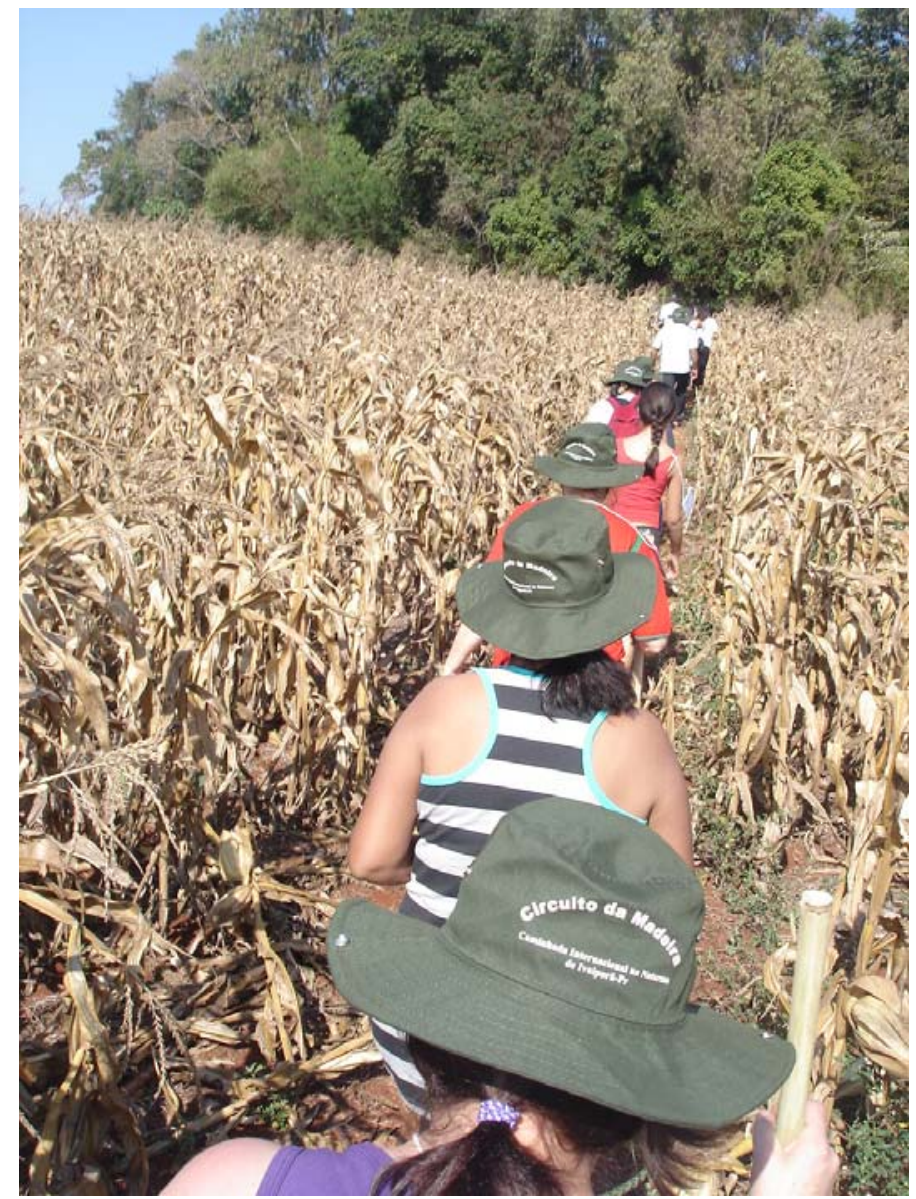

O relatório final da caminhada foi enviado aos municípios da região e às secretarias municipais. Como projeto de ação governamental os dados apresentados destacam a participação de 993 caminhantes, sendo 401 deles de fora do município de Ivaiporã $^{13}$. Além da participação intensa, o relatório salientou que a atividade movimentou quase vinte e cinco mil reais na cidade, gerando um lucro de oito mil. Estas estatísticas dizem algo sobre quais são os indicadores capazes de confirmar o sucesso da ação para um município que concebia a agricultura como única fonte de renda possível para as áreas rurais. Entretanto, deslocar a relação estabelecida entre os sujeitos e a paisagem sempre associada não a Natureza, mas a agricultura, implica em uma negociação das expectativas entre aqueles que planejam a caminhada e aqueles que caminham, entre as paisagens vividas e as paisagens imaginadas.

\footnotetext{
13 Além dos dados já apresentados, o relatório também mostra que os dois maiores grupos de idade dos caminhantes foi entre 11 e 20 anos (318) e entre 31 a 50 anos (273). A distribuição de gênero foi de 529 homens e 467 mulheres. A organização da caminhada envolveu, direta ou indiretamente, 135 pessoas.
} 


\section{“Mas não era para ser na Natureza?”: uma negociação de expectativas de paisagens}

A definição do trajeto da caminhada e seus possíveis problemas foram preocupações constantes dos organizadores do evento. As orientações da ONG Anda Brasil que, em certa medida, padroniza algumas características destas atividades, determina apenas que o percurso tenha média de dez quilômetros e que seja, preferencialmente, circular. As características deste trajeto, no entanto, são definidas localmente e dependem de seus idealizadores. No caso da caminhada em Ivaiporã, foi Ivaldete, responsável pelo turismo rural na EMATER, e alguns secretários do município, os que ficaram encarregados de elaborar o percurso.

Ao denominar a atividade de "Caminhada na Natureza” e não "Caminhada Ecológica”, os organizadores procuraram, segundo Ivaldete, explicitar que o foco era, sobretudo, os produtores da agricultura familiar.

É o seguinte, o objetivo é trabalhar a agricultura familiar, passar na pequena propriedade. Nossa parte ecológica é que a gente tenta passar a questão de preservação das trilhas, matas, mas o objetivo nosso é a propriedade rural, é o agricultor, para que ele possa gerar renda. Você viu lá hoje os móveis de madeira, artesanato, produção de alimentos, transformação de produto, então tudo isso para o produtor gerar renda. Não vai só no mato, mas passa por propriedades. Então ela não é só do mato, o objetivo é passar também por propriedades (...). A gente trabalha tudo dentro da agricultura familiar, trabalhando para potencializar aquilo que o pequeno agricultor produz para poder comercializar em conjunto. Como o artesanato, a gente procura fazer um trabalho em conjunto para poder comercializar em conjunto. Você cria um caminho que passe pela agricultura familiar. Então as nossas caminhadas têm esse objetivo: a agricultura familiar. Passar pelas propriedades, a gente vai passar amanhã por doze propriedades (Ivaldete).

Embora as caminhadas "na natureza” possam ter como efeito a geração e descoberta de outras fontes de renda para os produtores rurais, suas propriedades precisam ser transformadas, por meio de alguns elementos, de paisagens agrícolas em paisagens turísticas. A exploração de lugares potencialmente turísticos, aponta Rémy (1991), implica em uma espécie de subversão dos sentidos a eles atribuídos noutros momentos: a plantação de amoras que gerava renda com a colheita transforma-se em material pedagógico para os caminhantes, o tacho usado para fazer rapadura e que, conforme disse Seu Ivo, sempre fora escondido quando as visitas chegavam passa a ser lugar privilegiado para fotos, o suco de laranja tomado nas tardes torna-se suco ecológico.

Esta subversão dos sentidos atribuídos à paisagem do campo, no caso da Caminhada de Ivaiporã, foi obtida por meio de alguns artifícios, tais como a retirada de 
todas as cercas e o desvio das porteiras antes existentes pelo trajeto. Ainda que tenha atravessado doze propriedades, as marcas destes limites foram substituídas pelas diferenças naquilo que se produzia e cultivava em cada uma destas fazendas. Para Simmel (1996), são estas modificações na continuidade infinita dos elementos presentes na Natureza as que são capazes de fracionar o nexo ininterrupto das coisas e atribuir sentido a este "pedaço” de Natureza, isto é, de conformar uma paisagem.

A Natureza, que no seu ser e no seu sentido profundo nada sabe da
individualidade, graças ao olhar Humano que a divide e das partes
constitui unidades particulares, é reorganizada para ser a
individualidade respectiva que apelidamos de "paisagem"
(Simmel,1996:7)

Embora o autor pressuponha, em certa medida, a existência desta Natureza como um dado, uma realidade autônoma da relação com aqueles que a habitam, sua noção de paisagem aponta para uma indistinção entre aquele que observa e aquilo que é observado. A paisagem, que se constitui a partir da convergência para uma unidade particular de uma Natureza antes dispersa, ganha força de sentido naquilo que Simmel denomina de disposição anímica. Trata-se do que é comum a unidade que se constrói, mas que, ao mesmo tempo, não está "incluso em nenhum elemento singular desta paisagem” (Simmel,1996: 17). Ao conferir uma “marca” à caminhada, por exemplo, chamá-la de “Circuito da Madeira”, conforma-se esta disposição anímica que dá unidade a uma Natureza caótica por meio da atribuição de um sentido. Este sentido, no entanto, é apenas um sentido sugerido uma vez que nem os organizadores da caminhada, nem os caminhantes detêm o monopólio da produção de disposições anímicas, de paisagens.

Embora todos os caminhantes compartilhassem o trajeto a ser percorrido, a experiência da caminhada e a atribuição de sentidos relacionados à prática mostrou-se, diversas vezes, distintas e mesmo contraditórias. Como neste trecho do diário de campo:

Foi logo nos primeiros momentos de caminhada que percebi a quantidade de estudantes do ensino médio, inclusive de outras cidades. Estes estudantes - não sei se foram voluntariamente, ou não - pareciam estar em uma excursão, gritavam muito, um se esforçava mais do que o outro para se destacar. Após os primeiros metros na estrada rural, entramos em uma das únicas trilhas pela qual passaríamos. Na minha frente havia um casal e atrás uma turma de estudantes de um município vizinho. Na frente o homem falou para a mulher "Nossa, olha como o ar aqui [na trilha, na Natureza] é mais leve" e atrás o estudante acendia um cigarro, mas foi ponderado por outro que disse "o pessoal vem para o mato caminhar e você fuma?” Eles quebraram alguns galhos de árvore, gritavam sem razão e eu fiquei "preso" entre o grupo sem poder ultrapassá-los enquanto estávamos na trilha. Lamentei a situação. Mas agora fico pensando se fazia, para aqueles 
estudantes, alguma diferença aquela atividade ser naquele ambiente? (diário de campo de 22 de agosto de 2010)

O que parece estar em jogo é uma negociação constante entre as expectativas dos caminhantes projetadas sob a Natureza. Estas expectativas entre aqueles que caminham e aqueles que promovem a caminhada, entre aqueles que promovem um lugar turístico e aqueles que, até então, concebiam este espaço como lugar de trabalho, põe em relação narrativas, temporalidades, sentidos. Simon Schama nos dá algumas pistas destas articulações:

E, se, a visão que uma criança tem da Natureza já pode comportar lembranças, mitos e significados complexos, muito mais elaborada é a moldura através da qual nossos olhos adultos contemplam a paisagem. Pois, conquanto estejamos habituados a situar a Natureza e a percepção humana em dois campos distintos, na verdade, elas são inseparáveis. Antes de poder ser um repouso para os sentidos, a paisagem é obra da mente. Compõe-se tanto de camadas de lembranças quanto de estratos de rochas (Schama, 1996:17)

A construção de um trajeto que desse visibilidade a produção e às características da agricultura familiar proporcionou a emergência de determinados tipos de estruturas espaços-temporais, de certa regularidade rítmica da imaginação dos caminhantes que se adensava coletivamente a cada objeto explicitado, a cada alimento oferecido, a cada passo nas plantações que ressoasse na memória ganhando razões para durar, para dar unidade a um passado.

Em conversa com Ivaldete no dia que antecedeu a caminhada, a organizadora do evento narrou a dificuldade que tiveram para fazer um trajeto que passasse pelas plantações dos produtores rurais, mas que o esforço valeria a pena uma vez que isso seria uma forma de os caminhantes valorizarem os produtores e conhecerem como é o ciclo das plantações. No dia da caminhada, em um trecho ainda no início do trajeto, converso com Luiz, um caminhante de Ivaiporã, que diz: "Eu morei muitos anos no interior, mas aí fiz contabilidade e fui para a cidade e perdi o contato. Nossa, mas é muito legal vir aqui e lembrar de antigamente”. Noutro momento, enquanto atravessávamos uma plantação de milho ouvi uma mulher comentar com as amigas: “Ué! Mas não era caminhada na Natureza, cadê a Natureza?”

Ainda que o percurso da caminhada e os diversos dispositivos espalhados pelo trajeto privilegiassem determinada memória, imaginação, paisagem, são os caminhantes quem descobrem, articulam e colocam em evidência a existência da sobreposição das estruturas espaços-temporais que um percurso como este comporta. 


\title{
A Caminhada como prática do espaço
}

\begin{abstract}
Na Atenas contemporânea, os transportes coletivos se chamam metaphorai. Para ir para o trabalho ou voltar para casa, toma-se uma "metáfora" - um ônibus ou um trem. Os relatos poderiam igualmente ter esse belo nome: todo dia, eles atravessam e organizam lugares: eles os selecionam e os reúnem num só conjunto; deles fazem frases e itinerários. São percursos de espaços. (De Certau, 1994: 199)
\end{abstract}

Se a conseqüência mais evidente do que Michel De Certau afirma é que as estruturas narrativas têm valores de sintaxes espaciais, também é verdadeiro que os deslocamentos no espaço adquirem valores narrativos. Ao se deslocarem, os caminhantes moldam espaços, seguem por trajetos já traçados, mas também podem subvertê-los e reorganizá-los. Para De Certeau, o ato de caminhar é um espaço de enunciação com uma tríplice função, em que cada um dos termos encontra paralelo com a língua: é um processo de apropriação do sistema topográfico pelo pedestre - assim como o locutor se apropria e assume a língua; é uma realização espacial do lugar assim como o ato da palavra é uma realização sonora da língua; implica o estabelecimento de relações entre posições diferenciadas - assim como a língua coloca seus falantes em relação (De Certau, 1994:177). As caminhadas dos pedestres tornamse, conforme esta perspectiva, retóricas ambulatórias que moldam percursos como os falantes moldam frases.

Estas retóricas são formuladas, para De Certeau, a partir da articulação entre lugar e espaço. Lugar é aquilo que está estabelecido, a disposição das coisas conforme, por exemplo, o planejamento do trajeto elaborado pelos coordenadores da caminhada, já espaço é o lugar praticado, é o efeito da criatividade que desloca, transgride o que está prescrito. Neste sentido, o espaço está para o lugar assim como a língua falada está para a gramática.

Ao lançarmos mão do estabelecimento desta relação entre aqueles que falam e aqueles que caminham, passamos a nos balizar por uma espécie de sombra em que todas as funções e práticas do idioma encontram correspondentes no que De Certeau chama de retóricas ambulatórias. Por um lado, esta hipotética paridade permite que o ato ordinário de caminhar, de compor percursos adquira “dignidade de atenção”, mas por outro, limita as múltiplas possibilidades de expressão deste ato como detentor de características específicas de manifestação, para além daquelas do idioma. 
Bachelard, em “A poética do espaço” (1984), aponta para uma perspectiva que reconhece a importância desta relação entre sujeito e espaço sem, contudo, constrangêla a uma referência lingüística. Para o autor, a imaginação trabalha nos espaços verdadeiramente habitados a partir de imagens capazes de ditar a dinâmica da relação entre passado, presente e futuro. O jogo temporal se dá a partir de uma espacialidade que não designa apenas um ambiente exterior ao sujeito, mas que o inclui, uma vez que a imagem, o espaço e o tempo não se dão nem no sujeito, nem fora dele, mas a partir da relação.

Aqui o espaço é tudo. Porque o tempo não mais anima a memória. A memória - coisa estranha! - não registra a duração concreta, a duração no sentido bergsoniano. Não se podem reviver as durações abolidas. Só se pode pensá-las na linha de um tempo abstrato privado de toda densidade. É pelo espaço, é no espaço que encontramos os belos fósseis de uma duração concretizados em longos estágios (Bachelard, 1984:203)

Assim, é na medida em que estabelecemos relações, constituímos histórias, e percorremos o espaço, que ele toma forma. Trata-se de concebê-lo não mais como externo aos Humanos, mas como constitutivo das dinâmicas sociais e temporais daqueles que o habitam, bem como constituído pelas relações nele engajadas, tornandose, num jogo relacional, modificador das práticas nele produzidas, mas também modificado por elas.

A projeção de um lugar para se caminhar por parte dos organizadores da caminhada de Ivaiporã e a prática de um espaço por parte dos caminhantes, coloca em evidência não apenas a relação intrínseca e indistinta entre um sujeito que habita e um mundo que é habitado, como também evidencia a multiplicidade de imagens, no sentido bachelardiano, que as ações em torno de uma caminhada - seja de elaboração do trajeto, seja de sua feitura - comportam.

A elaboração do trajeto da Caminhada “na natureza” de Ivaiporã colocou organizadores e caminhantes em dilemas contraditórios, mas de mesma ordem. Enquanto os primeiros estavam, nas palavras de Ivaldete, uma das responsáveis pelo evento, buscando fazer uma "caminhada para que as pessoas conheçam e valorizem o trabalho da agricultura familiar”, os segundos se questionavam, conforme disse Junior., um caminhante da cidade vizinha, “porque caminhar nesse lugar que sempre passo?”

A proposta de demarcar a diferença entre caminhada na Natureza e caminhada ecológica como sendo o fato de a primeira contemplar a ação antrópica e a segunda privilegiar apenas uma paisagem "intocada”, produz seus efeitos na elaboração do 
percurso e na receptividade dele por parte dos caminhantes. A paisagem em que caminhamos era, de modo geral, entre trigais, campos de aveia, plantações de amora para alimentar bichos-da-seda o que despertou certo desconforto em parte dos caminhantes que estavam interessados em "Natureza mesmo", como um grupo de senhoras da cidade me dizia. Em contrapartida, para os organizadores do evento, este era o pronto forte do percurso que elaboraram, uma vez que permitia um contato maior com o produtor.

A caminhada, conforme a concebo, promove este deslocamento, tanto objetivo como subjetivo, e o que interessa aqui talvez não seja nem um e nem outro como elementos autônomos, mas enquanto relacionados. Flaneurs, voyeurs, peregrinos, caminhantes não são denominações que se constituem enquanto tal por conta de um território privilegiado a cada um deles, mas na medida em que os espaços são mobilizados subjetivamente de maneiras específicas.

\section{À guisa de uma conclusao: mas por que na natureza?}

Mas afinal, o que faz com que mil pessoas em uma cidade do interior do Paraná se mobilizem para realizar uma caminhada "na natureza”? Em que medida esta prática diz algo sobre uma discursividade ambiental mais ampla e sobre arranjos políticos locais? Se fosse uma caminhada "na cidade" estes caminhantes participariam da atividade? Embora as imagens, narrativas e sentidos atribuídos à Natureza tenham sido diversos tanto na elaboração da caminhada, como no ato de caminhar, o que parece estar em jogo é o atravessamento desta prática por discursividades mais amplas que apontam para uma expansão de certa ética ecológica. Por um lado, inscrever a Caminhada Internacional na Natureza de Ivaiporã em um contexto de práticas ambientais remete a uma dinâmica entre o discurso global e sua recepção e transformação nos âmbitos do contexto local, por outro, parece estar relacionado com uma incorporação coletiva e, ao mesmo tempo, individual desta ética de relação Humano-Natureza. Detenho-me, a seguir, brevemente, nestes dois pontos.

O imbricamento entre os níveis local e global questiona uma visão bastante disseminada da força homogeneizadora dos processos globais e da passividade das culturas locais diante desta força. Afirmar uma hipotética sujeição das culturas locais aos discursos universalizantes sobre o ambiente seria o mesmo que desconsiderar sua 
autonomia e intencionalidade histórica e desconsiderar a potencialidade do local na conformação dos processos globais.

A propósito das reflexões acerca da tensão entre o local e o global na constituição de práticas singulares, destaco a contribuição de Marshall Sahlins (1997b, 1997c). Tomando como ponto de partida a inexorabilidade da noção de cultura enquanto objeto privilegiado da antropologia, Sahlins se contrapõe aos paradigmas que aderem a certo “pessimismo sentimental” e que tendem a conferir à globalização capitalista o poder de dissolver a diversidade das culturas numa única "aldeia global”, onde a singularidade e a criatividade locais nada mais seriam do que "versões locais da civilização Ocidental” (Sahlins, 1997b: 42). Desde esta perspectiva, a expansão do capitalismo desencadearia um processo de “desculturação” das populações locais que se tenderiam a desaparecer sob a força avassaladora dos processos hegemônicos globais.

Na contramão desta perspectiva, respaldado por um grande número de exemplos etnográficos de diversas regiões do planeta, Sahlins contradiz esta hipótese do desaparecimento e da assimilação das culturas locais por uma hipotética cultura global. Estas etnografias, longe de evidenciarem a presença de um sistema mundial monológico e determinista, tornam patente a capacidade das culturas locais em manipularem e agenciarem, a partir de suas próprias lógicas e dinâmicas, os elementos culturais exteriores e diversos de sua tradição que a globalização lhes torna acessíveis. Esta visão do processo de globalização desde a experiência local é o que permite perceber o papel ativo e contra-hegemônico das populações periféricas e de grupos vulneráveis, o qual Sahlins chamou de “indigeneização da modernidade”, em contraposição ao conceito de globalização.

Este giro interpretativo da globalização para a indigeneização, proposto por Sahlins, constitui-se como importante baliza teórica para nortear a percepção e análise dos processos pelos quais a questão ambiental é incorporada na experiência coletiva de grupos e movimentos sociais e na formação de sujeitos ecologicamente orientados. As práticas, as táticas e as estratégias locais de incorporação e institucionalização da questão ambiental nos campos do turismo e do desenvolvimento rural têm a capacidade de definir o que seja o ambiental. Isto é, ao inscrever a atividade acompanhada em Ivaiporã numa discursividade ecológica mais ampla e, ao mesmo tempo, privilegiar as singularidades locais na constituição dos sentidos desta prática, aposto em uma dinâmica específica entre integração e diferenciação, exterior e interior, local e global. Assim, na medida em que tomo como premissa que não há um sentido real ou 
originários de ambiental, ao qual todos os outros significados se distanciam ou se aproximam, procuro compreender os seus múltiplos sentidos como parte de um jogo que funciona a partir de um conjunto de relações e agenciamentos locais de questões globais e vice-versa (Steil, 2010; Carvalho e Toniol, 2010)

Esta dinâmica entre global e local em uma atividade como a Caminhada em Ivaiporã, nos coloca diante da problemática do engajamento dos caminhantes como resultado de uma incorporação tanto individual como coletiva de um ideário ecológico.

Conforme procurei apontar ao longo do texto, a entrada das questões ambientais na agenda política do município deu-se, por paradoxal que possa parecer, via necessidade de desenvolvimento da região. Para os organizadores do evento na cidade, a caminhada foi concebida como uma alternativa para a geração de renda nas áreas rurais. No âmbito estadual, conforme pude perceber a partir de conversas com representantes do Estado envolvidos na atividade, a caminhada “na natureza” de Ivaiporã está inscrita em um projeto transversal, chamado "Caminhadas do Paraná”, que atravessa as secretarias de turismo, meio ambiente e agricultura. Esta composição diversificada implica que interesses distintos estão em jogo entre os planejadores de um mesmo programa. Já o envolvimento do Ministério do Desenvolvimento Agrário apóia o projeto das caminhadas como parte de uma série de mecanismos que procura desenvolver o turismo rural na agricultura familiar. Esta série de articulações que são objetificadas em uma caminhada no interior do Paraná contribui para institucionalizar certa ética ambiental.

A referência a este processo de institucionalização que a caminhada "na natureza” proporciona encontra paralelo na instauração dos códigos de conduta na formação da corte analisada por Elias (1990,1993). O processo civilizador, para Elias, pode ser compreendido, em certa medida, a partir da transformação de comportamentos. Aqueles sujeitos cujo pertencimento a nobreza não era garantido pela hereditariedade precisavam explicitar distinção interior em suas posturas, gestos, vestuário, expressões faciais exteriores. Ao lançar mão deste paralelo, procuro apresentar um duplo movimento em que tanto há uma configuração que promove determinada conduta dos indivíduos, como também estas condutas individuais instituem, colocam a prova e reafirmam grades de diferenciação estabelecidas, trata-se da noção eliasiana de habitus (Elias, 1994). O que procuro apontar é para uma via de mão dupla em que a promoção da caminhada “na natureza” como ação governamental promove uma ética de conduta na relação com a Natureza entre os caminhantes e, ao mesmo tempo, a adesão a este 
evento depende, em certa medida, do compartilhamento de determinadas estruturas de sentido que façam com que o ideário ecológico encontre razão para durar.

\section{Referências:}

BACHELARD, Gaston. A filosofia do não : filosofia do novo espírito científico. 3. ed. São Paulo: Presença, 1984

BARRETTO FILHO, Henyo T. Da nação ao planeta através da Natureza: uma abordagem antropológica das unidades de conservação de proteção integral na Amazônia brasileira. São Paulo, 2 vol., FFLCH/USP, 2001. Tese Doutorado em Antropologia Social.

BAUBÉROT, Arnaud. "La nature éducatrice”. In: Ethnologie française 4/2001 (Vol. 31), p. 621-629.

BÍBLIA SAGRADA. Edição pastoral. São Paulo: Paulus. BAZAGLIA, Paulo (responsável pela edição eletrônica). em: http://www.paulus.com.br/BP/_INDEX.HTM.

BOAS, Franz. "Alguns problemas de metodologia nas ciências sociais". In: Antropologia Cultural. CASTRO, Celso, org. Rio de Janeiro: Jorge Zahar, 2003.

CHAVEZ, Fátima Almada. A questão ambiental na esfera pública e a democracia no Paraguai. Dissertação de mestrado em Desenvolvimento Rural, Universidade Federal do Rio Grande do Sul, Porto Alegre, 2004.

CARVALHO, Isabel Cristina de Moura; TONIOL, Rodrigo. “Ambientalização, cultura e educação: diálogos, traduções e inteligibilidades possíveis desde um estudo antropológico da educação ambiental”. In: Revista Eletrônica do Mestrado em Educação Ambiental. Revista Eletrônica do Mestrado em Educação Ambiental, v. Esp., p. 1-12, 2010.

CARVALHO, Isabel Cristina de Moura. A invenção ecológica: narrativas e trajetórias da educação ambiental no Brasil. 2 ed. Porto Alegre: Editora da UFRGS, 2002.

CARVALHO, I. C. M. "Paisagem, historicidade e ambiente: as várias Naturezas da Natureza”. Rivista Confluenze, v. 1, p. 136-157, 2009.

DE CERTEAU, Michel. A invenção do cotidiano: artes de fazer. Petrópolis, Vozes, 1994.

DESCOLA, Philippe e Gísli Pálsson. Nature and Society - Anthropological perspectives. London: Routledge, 1996.

DUARTE, Luiz Fernando Dias. "A pulsão romântica e as ciências humanas no ocidente”. Rev. bras. Ci. Soc., São Paulo, v. 19, n. 55, June 2004.

ECKERT, Cornelia e ROCHA, Ana Luiza Carvalho da. O tempo e a cidade. Porto Alegre, Ed. UFRGS, 2005

ELIAS, N. O processo civilizador; uma história dos costumes. v.1. Rio de Janeiro, Zahar, 1990.

ELIAS, N. O processo civilizador; formação do Estado e civilzação. v.2. Rio de Janeiro, Zahar, 1993.

ELIAS, Norbert. A sociedade dos indivíduos. RJ, Jorge Zahar, 1994.

EVANS-PRITCHARD, Edward. E. Os Nuer. São Paulo: Perspectiva, 2005

FABIAN, Johannes. “A prática etnográfica como compartilhamento do tempo e como objetivação”. Mana. 2006, vol.12, n.2, pp. 503-520

FABIAN, Johannes. Time and the other : how anthropology makes its object. New York: Columbia University Press, 1983. 
FERRY, Luc. A nova ordem ecológica: a árvore, o animal e o homem. São Paulo: Ensaio, 1994.

GEERTZ, Clifford. A interpretação das culturas. Rio de Janeiro, Zahar, 1978.

GODOY, Ana. Da imensidão selvagem às áreas protegidas: inventando Naturezas, criando lugares. Dissertação de mestrado. São Paulo, PUC, jun. 1999

GODOY, Ana. “O modelo da Natureza e a Natureza do modelo". São Paulo Perspec. [online]. 2000, vol.14, n.4, pp. 129-138.

GOLDMAN, Marcio. Alguma antropologia. Rio de Janeiro: Relume Dumará, 1999.

GOLDMAN, Márcio. "Os Tambores do Antropólogo: Antropologia Pós-Social e Etnografia”. Ponto Urbe. Revista do NAU da USP, v. 3, p. 1-11, 2008.

JOUTY, S. "Connaissance et symbolique de la montagne chez les érudits médiévaux". In: Revue de géographie alpine. 1991, Tome 79 N4. pp. 21-34.

LATOUR, Bruno. Jamais fomos modernos. Rio de Janeiro: Ed. 34, 1994

LATOUR, Bruno. Reflexão sobre o culto moderno dos deuses fe(i)tiches. São Paulo: EDUSC, 2002.

LAVENIR, Catherine. “Camper en 1900: De l'ascèse laïque au loisir élégant”. In: Ethnologie française 2001, vol. 31, nº 4, pp. 631-640

LEITE LOPES, J. S. (Org.). A Ambientalização dos Conflitos Sociais; Participação e Controle Público da Poluição Industrial (coordenador). 1. ed. Rio de Janeiro: RelumeDumará, 2004.

LÉVI-STRAUSS, Claude. Antropologia estrutural. 5.ed. Rio de Janeiro: Tempo Brasileiro, 1996.

MAJASTRE, J. O. "La montagne en ses thermes : de Montaigne à Michelet”. In: Revue de géographie alpine. 1991, Tome 79 N4. pp. 41-56.

MERLEAU-PONTY, Maurice. Fenomenologia da Percepção. São Paulo, Martins Fontes, 1994.

PÁDUA, José Augusto. "Natureza e projeto nacional: as origens da ecologia política no Brasil”. In: PÁDUA, J. A. (org.). Ecologia e política no Brasil. Rio de Janeiro, Espaço e Tempo/Iuperj, 1987, pp. 11-62.

RÉMY, Knafou. "L'invention du lieu touristique : la passation d'un contrat et le surgissement simultané d'un nouveau territoire”. In: Revue de géographie alpine. 1991, Tome $79 \mathrm{~N}^{\circ}$ 4. pp. 11-19.

SHALLINS, Marshall. Ilhas de história. Rio de Janeiro: Jorge Zahar, 1997a.

SHALLINS, M. “'O pessimismo sentimental' e a experiência etnográfica: por que a cultura não é um “objeto” em via de extinção (parte I)”. Mana. Rio de Janeiro, v. 3, n.1, p 41-73, 1997b.

SHALLINS, M. “'O pessimismo sentimental’ e a experiência etnográfica: por que a cultura não é um “objeto” em via de extinção (parte II).” Mana. Rio de Janeiro, v. 3, n.2, p:103-150, 1997c.

STEIL, Carlos Alberto. Ambientalização Social e Religião. Projeto de pesquisa CNPq, 2010. Porto Alegre: Universidade Federal do Rio Grande do Sul.

SCHAMA, Simon. Paisagem e memória. SP, Companhia das Letras, 1996.

SCHWARCZ, Lilia K. Moritz. "Questões de fronteira: sobre uma antropologia da história”. Novos estud. - CEBRAP ]. 2005, n.72 ,pp. 119-135

SIMMEL, G. “A filosofia da paisagem”. Revista Política \& Trabalho, João Pessoa, n¹2, 1996.

THOMAS, Keith. O homem e o mundo natural: mudança de atitude em relação às plantas e aos animais, 1500-1800. São Paulo: Companhia das Letras, 2010.

VIVEIROS de Castro, Eduardo. A inconstância da alma selvagem. São Paulo, Cosac \& Naify, 2002. 